\title{
Analysis of natural-production conditions for timber harvesting in European North of Russia
}

\author{
Ilya Shegelman ${ }^{1}$, Pavel Budnik ${ }^{1, *}$, Vyacheslav Baklagin ${ }^{2}$, Oleg Galaktionov ${ }^{1}$, \\ Ivan Khyunninen ${ }^{1}$, Artem Popov ${ }^{1}$ \\ ${ }^{1}$ Petrozavodsk State University, Lenin Str., 33, 185910, Petrozavodsk, Russia \\ ${ }^{2}$ Northern Water Problems Institute of the Karelian Research Centre of the Russian Academy of Sciences, \\ Aleksander Nevsky Str., 50, 185030, Petrozavodsk, Russia
}

\begin{abstract}
Natural-production conditions determine operational efficiency of logging machines. This influence needs to be taken into account at different levels of forest management. It is necessary to allocate areas with similar natural-production conditions for effective forest management. It allows simplifying the decision making process for selecting logging technology and machines. The purpose of this study was to establish areas with similar natural and production conditions in the European North of Russia (ENR). In addition, for small enterprises, we recommend logging technologies and logging machines that can be used in established areas. We determined the indicators of the natural-production conditions of ENR regions and compared them. Cluster analysis was used to compare the indicators. We found that ENR can be divided into three main zones A, B, C and two subzones B1 and B2 with similar natural-production conditions. In the zones A, B and the subzones B1 and B2, small logging enterprises should use a harvester and a forwarder. In the zone $\mathrm{C}$, the enterprises can use a logging system including a harvester and a forwarder or a logging system including a feller buncher, a skidder and a processor. The logging system should be based on the light class of logging machines for the zone A, the medium class or the heavy class for the zones B, C and the subzones B1, B2, the heavy class of machines for the zone $\mathrm{C}$.
\end{abstract}

Key words: natural-production conditions; tree size; relief; soil conditions; timber volume; forest species composition, logging machines, cluster analysis

Editor: Tomáš Hlásny

\section{Introduction}

Natural and production conditions determine operational efficiency of logging machines (Häggström et al. 2016; Alam et al. 2014; Nurminen et al. 2006). This influence needs to be taken into account at different levels of forest management: operational, tactical and strategic.

In order to assess the influence of natural-production conditions it is necessary to define the factors of such impact. It can be performed based on analysis of studies regarding the impact of natural-production conditions on operational efficiency of logging machines.

The influence of timber volume per hectare (ha), sizes of trees on the efficiency of harvester has been studied rather thoroughly (Kormanek et al. 2018; Laitila et al. 2013; Jiroušek et al. 2007; Ovaskainen et al. 2005; Kärhä et al. 2004; Eliasson 1998; Glöde 1999). These studies indicate that harvester efficiency increases with the increase of tree size. However such increase is not endless. For certain models of machines there are specific tree sizes the increase of which leads not to efficiency improving, but - on the contrary - to its loss (McNeel \& Rutherford 1994; Kärhä et al. 2004).

Numerous research works reveal that there is a growth of diesel fuel consumption with the increase of sizes of treated trees and their species (Kellogg et al. 1994; Ackerman et al. 2017).

Large-size tree trunks can be a severe restriction to logging with the use of logging machines. For example, large trees and small timber volume per ha is a serious problem for using harvesting machines in rainforests (Castro et al. 2016).

The influence of timber volume per ha and sizes of trees on the operation of forwarders has been extensively studied (Kellogg \& Bettinger 1994; Tufts \& Brinker 1993). The studies show that the efficiency of forwarders increases with the increase of timber volume per ha and sizes of trees. 
When it comes to the efficiency of timber harvesting, soil conditions are often determinant (Proto et al. 2018; Rozitis et al. 2017). The speed of skidding machine depends on the quality of skidding road surface. When skidding or transporting wood on soils with low bearing capacity, a track appears fast thus increasing resistance to motion. It leads to decline in productivity, fuel consumption increase and growth of the load on transmission.

A lot of works give evidence of negative impact of logging machines on soil during the process of timber harvesting (Klaes 2016; Reza et al. 2009; Schack-Kirchner et al. 2007). The negative impact is expressed in tracking and soil panning, preventing further timber regeneration. Waterlogged soils are especially vulnerable to such harm.

Relief of the terrain markedly affects the efficiency of logging machines and imposes restrictions upon their use (Strandgard et al. 2017; Tiernan et al. 2004). For instance, excavator-based harvesters are uncommonly used in Finland and Russian north despite their advantages over harvesters with specialized chassis (Palander et al. 2012, Bergroth et al. 2006; Wang et al. 2002). This is mainly due to restrictions on the use of such machines, even on small slopes.

Species of wood have structure and development specifics that substantially influence operational efficiency of logging machines. Therefore, species composition of stands shall be considered when analyzing natural-production conditions. Besides, species composition determines economic value of a forest stand. Economic value of woods depends on a wide range of factors: structure of stand, age, conditions of habitat and others. In the European part of Russia coniferous forests are more valuable and spreading than deciduous. Economic value of forest stand defines a forest entrepreneur's possibilities to use more progressive machinery with the highest efficiency relating to performance and environmental safety at the expense of generated profits.

Peculiarities of species structure mostly influence operational efficiency of logging machines performing the following operations: felling, limbing, length bucking. Species' influence on operational efficiency of logging machines has been studies not so extensively as other earlier mentioned factors of natural-production conditions (Pētersons 2014). In general, many specialists have acknowledged that operation of logging machines is more productive and less problematic in coniferous forest stands than in deciduous forest stands.

Taking into account the influence of natural and production conditions of logging requires a high level of forest management. This implies the ability to analyze a large amount of information and make management decisions based on the analysis. In addition, a high degree of awareness of natural and production conditions of the forest resource base of the enterprise is required. Therewith it requires a wide fleet of logging machines, which gives the possibility to choose the most suitable logging machines for the specific area of the forest resource base.
This approach in forest management can be implemented in large enterprises. Small enterprises cannot take this approach. As a rule, they are contractors and their fleet includes one or two complexes. There is limited information on studies in substantiation of logging technology and logging machines for such enterprises. In Russia, the problem is complicated by the fact that small enterprises have to work in forest areas that are located in different subjects of the Russian region, and sometimes even in neighboring subjects of Russia. Thus, taking into account the size of the subjects of the Russia, enterprises operate in various natural and production conditions but are forced to use a limited fleet of logging machines.

We suppose that for small enterprises logging technology and logging machines should be universal and provide an opportunity to work in forest areas with a wide variety of natural and production conditions. However, at the same time, it is necessary to ensure that the technical characteristics of the logging machines are not excessive. For example, the use of logging machine in a small forest, which is designed to work in a large forest.

This approach can be implemented by solving the following tasks. First, territories with similar natural and production conditions should be allocated. At the same time, the allocated territories should be comparable in scale with forest areas, which the enterprises work. It allows simplifying the decision making process for selecting logging technology and machines. Secondly, the development of general recommendations on the applied logging technologies and logging machines for the allocated territories.

At the same time, we suppose that an objective approach to solving these problems can be the use of weighted average values that characterize the natural and production conditions of the allocated territories and variance of the values. This approach allows ensuring the universality of the selected technologies and logging equipment, as well as the use of logging machines with non-excessive technical characteristics.

The latest definition of territories with similar natural-production conditions in Russia was carried out in the eighties of the last century (Vinogorov 1986). The study was performed on the scale of the Soviet Union. Sizes of trees in forest stand and relief were the main indicators of natural-production conditions. However, the above research shows that it is necessary to take into account a greater number of natural-production conditions indicators. A number of other factors shall be also taken into account: soil conditions, timber volume per hectare, species composition of stands, location of merchantable forest and its accessibility. Besides, Vinogorov's work (1986) does not consider specific features of certain regions.

The purpose of this study was to establish areas with similar natural and production conditions in the European North of Russia (ENR). In addition, the aim of the study was to develop recommendations for the use of logging technologies and logging machines for the established areas. 


\section{Materials and methods}

\subsection{Study outline and methods}

The researches have included the following steps: 1) collecting data for defining natural-production conditions indicators of ENR; 2) comparing of the indicators and identifying zones with similar the natural-production conditions; 3) confronting of technical characteristics of logging machines with natural-production conditions and development of recommendations for using logging machines in the identified zones.

The step 2 contained three sub-steps. We calculated the values of the indicators at the first sub-step. At the second sub-step, we combined indicators into sets describing various aspects of natural-production conditions. At the third sub-step, we compared the sets and based on this identified zones with similar natural-production conditions. Tree clustering analysis was applied in the third sub-step. We employed single linkage for the linkage rules and Euclidean distances (ED). Tree clustering analysis was performed using STATISTICA on a PC.

The step 3 contained four sub-steps. We collected data on the technical characteristics of logging machines and data on their application at the first sub-step. At the second sub-step, we determined the feasibility of using models of logging machines in conditions of the identified zones. At the third sub-step, we divided logging machines into classes depending on its technical characteristics. At the last sub-step, we have developed recommendations for using the models of logging machines in the identified zones.

Method of expert evaluation was used in the step 3. The method had two stages. At the first stage, we determined the possibility of using the models of logging machines in the conditions of identified zones. To do this, we compared the technical characteristics of logging machines models and the natural-production conditions of zones. We took into account the recommendations of the manufacturer of the models of logging machines and information about their application. At the second stage, experts were involved. The experts were logging foremen and operators of logging machines. Each expert was invited to evaluate and comment on the results obtained in the first stage. The results were then analyzed and summarized.

\subsection{Study region}

Study region is European North of Russia (Fig. 1). ENR includes: Murmansk Region, the Republic of Karelia, Arkhangelsk Region, Vologda Region, Komi Republic, Nenets Autonomous Area. More than $40 \%$ of forest resources of Russian European part are concentrated on the territory of ENR, and forest and woodworking industries are among the main ones in the economic structure.

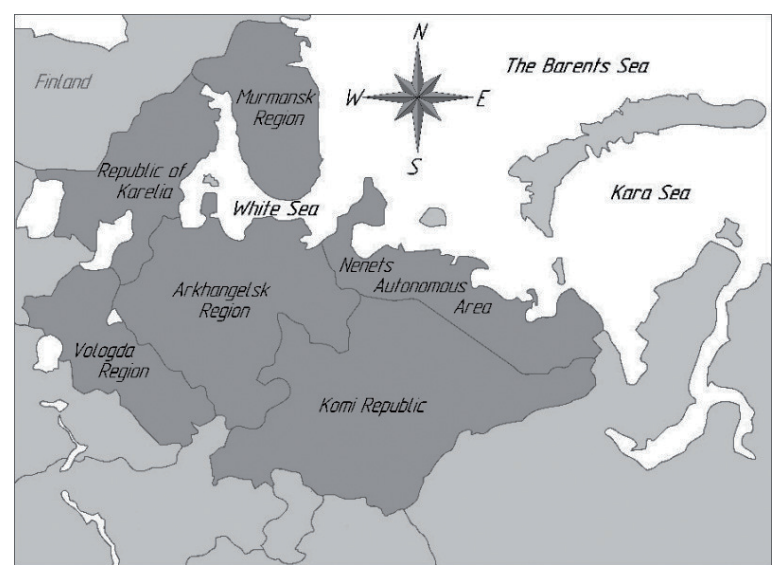

Fig. 1. Location of the ENR regions.

This study has not considered Nenets Autonomous Area. The reason for this is that timber resources of $18.2 \mathrm{mln} . \mathrm{m}^{3}$ are negligible in comparison with the other regions included into ENR. Besides Nenets Autonomous Area scarcely carries our works on timber harvesting. As reported by the Federal Forestry Agency felling volume in 2017 will be only 1.9 thous. $\mathrm{m}^{3}$.

Fig. 2 shows comparative diagrams of timber resources and the intensity of timber harvesting in ENR regions.

More than half of timber resources in ENR are situated in Komi Republic $-3114 \mathrm{mln} . \mathrm{m}^{3}$ and Arkhangelsk Region - 2688 mln. m³ (Fig. 2A). However, in the context of timber harvesting and applied machines, it is reasonable to assess timber resources in mature and old growth forests, situated on the territory of merchantable forests. According to the RF legislation industrial harvesting are conducted in merchantable forests. In total timber resources of Komi Republic 65\% fall to the share of mature and old growth forests in merchantable forests. In other ENR regions this share is less than $50 \%$ : Arkhangelsk Region - 46\%, Vologda Region - 48\%. In the Republic of Karelia only $29 \%$ fall to the share of mature and old growth forests in merchantable forests.

Utilization rate of timber resources can be evaluated based on felling volume and annual allowable cut use. Annual allowable cut is a scientifically grounded volume of sustainable yield.

According to the Federal Forestry Agency the largest wood volume in 2017 was harvested by Vologda and Arkhangelsk Regions $-15.6 \mathrm{mln} . \mathrm{m}^{3}$ and $12.7 \mathrm{mln} . \mathrm{m}^{3}$, respectively (Fig. 2B). Despite the greatest timber resources in mature and old growth forests in merchantable forests among other ENR regions, Komi Republic takes the third place in felling volume $-8.7 \mathrm{mln}$. $\mathrm{m}^{3}$. It is basically explained by lower intensity of timber harvesting in the republic. Thus, when the share of annual allowable cut development in Arkhangelsk Region, Vologda Region and the Republic of Karelia is more than $50 \%$, it is only $27 \%$ in Komi Republic (Fig. 2C). The Republic of Karelia has the highest percentage of annual allowable cut development $-64 \%$. 
A.

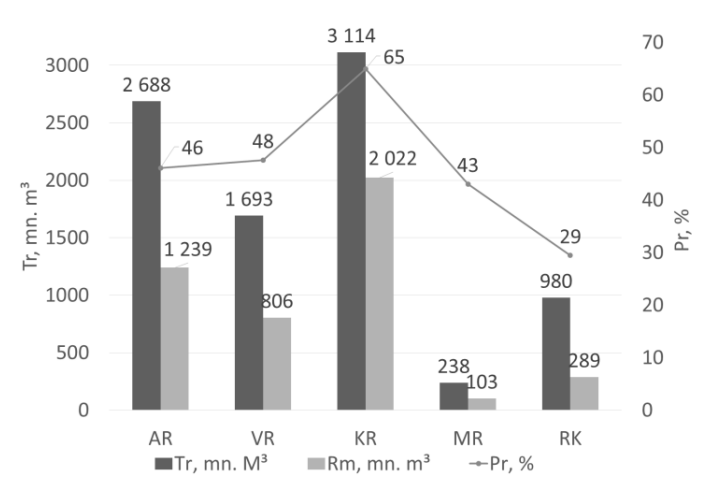

B.

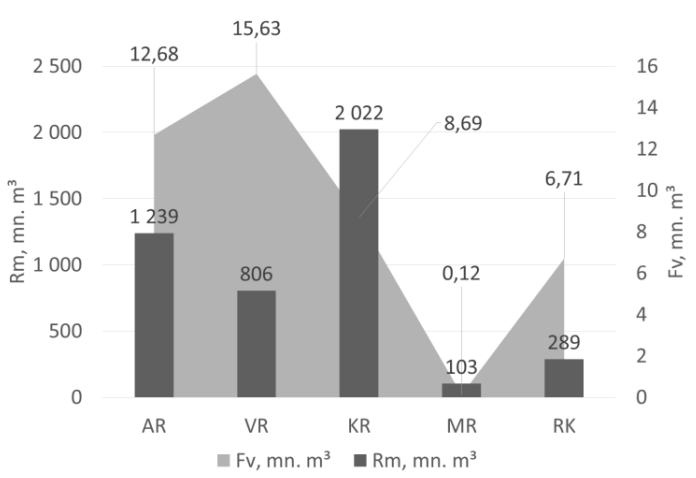

C.

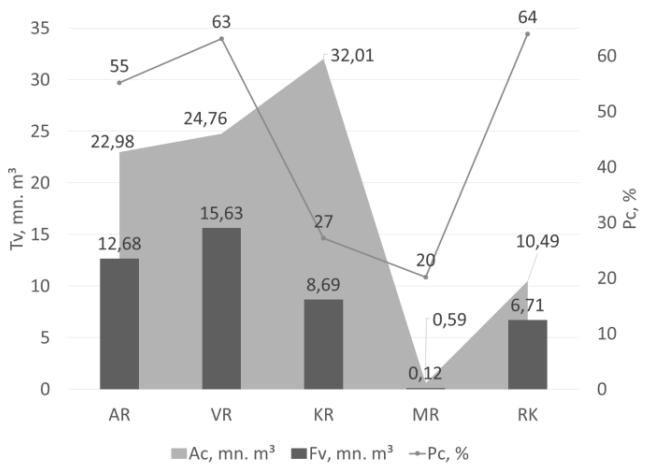

Fig. 2. Comparative diagrams of timber resources and the intensity of timber harvesting in ENR regions where Adistribution of timber resources and resources of mature and old growth forests in merchantable forests, B distribution of resources of mature and old growth forests in merchantable forests and felling volumes in 2017, C distribution of resources of mature and old growth forests in merchantable forests and felling volumes in 2017, $\operatorname{Tr}$ timber resources, $\operatorname{Pr}$ percent of resources of mature and old growth forests in merchantable forests in timber resources, $R m$ resources of mature and old growth forests in merchantable forests, $F v$ felling volumes in 2017, $T v$ timber volume, $P c$ percent of reclaiming of annual allowable cut, $A c$ annual allowable cut, $A R$ Archangelsk region, $V R$ Vologda Region, $K R$ Komi Republic, $M R$ Murmansk region, $R K$ The Republic of Karelia.

\subsection{Indicators of natural-production conditions}

We propose to compare natural-production conditions of ENR regions by comparing a number of indicators. Table 1 shows the list of indicators and their values for ENR regions. Table 2 shows sources of indicators data.

Table 1. The list of natural-production conditions indicators.

\begin{tabular}{|c|c|c|c|c|c|c|c|}
\hline \multirow[b]{2}{*}{ No } & \multirow[b]{2}{*}{ Indicator } & \multirow[b]{2}{*}{ Unit } & \multicolumn{5}{|c|}{ Indicator values } \\
\hline & & & 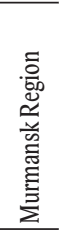 & 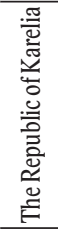 & 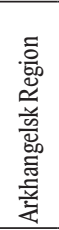 & 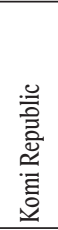 & 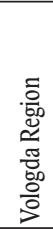 \\
\hline 1 & Average diameter of forest stands & & 20 & 22 & 21 & 22 & 20 \\
\hline 2 & The most common class diameter & {$[\mathrm{cm}]$} & 12 & 16 & 16 & 20 & 16 \\
\hline 3 & Maximum diameter class & & 48 & 56 & 52 & 56 & 52 \\
\hline$\overline{4}$ & Average volume of stem & & 0.2 & 0.2 & 0.2 & 0.2 & 0.3 \\
\hline & Maximum volume of stem & {$\left[\mathrm{m}^{3}\right]$} & 0.2 & 0.3 & 0.3 & 0.4 & 0.42 \\
\hline & Minimum volume of stem & & 0.2 & 0.1 & 0.2 & 0.1 & 0.3 \\
\hline 7 & Average height of trees & {$[\mathrm{m}]$} & 18 & 21 & 21 & 21 & 25 \\
\hline 8 & Quality class & & 5 & 4 & 4 & 4 & 3 \\
\hline 9 & Slope ratios Up to 15 degrees & & 99.9 & 100 & 100 & 99.8 & 100 \\
\hline 10 & Slope ratios $16-25$ degrees & & 0.1 & 0 & 0 & 0.2 & 0 \\
\hline 11 & Slope ratios 26 and more degrees & & 0 & 0 & 0 & 0 & 0 \\
\hline 12 & Ratios of class 1 of soil conditions & {$[\%]$} & 16 & 8 & 3 & 4 & 1 \\
\hline 13 & Ratios of class 2 of soil conditions & & 74 & 32 & 27 & 30 & 32 \\
\hline 14 & Ratios of class 3 of soil conditions & & 3 & 38 & 30 & 18 & 34 \\
\hline 15 & Ratios of class 4 of soil conditions & & 7 & 22 & 40 & 48 & 33 \\
\hline 16 & Timber volume per ha & & 44 & 102 & 120 & 101 & 168 \\
\hline 17 & Minimal timber volume per ha & {$\left[\mathrm{m}^{3}\right]$} & 29 & 70 & 81 & 57 & 126 \\
\hline 18 & Maximal timber volume per ha & & 53 & 200 & 275 & 160 & 229 \\
\hline 19 & Proportion of pine in the stand & & 53.8 & 52.4 & 21.9 & 27.4 & 23.4 \\
\hline 20 & Proportion of spruce in the stand & & 34.7 & 35.9 & 65.1 & 66.5 & 26.8 \\
\hline 21 & Proportion of birch in the stand & {$[\%]$} & 11.5 & 9.9 & 10 & 0.2 & 36.1 \\
\hline 22 & Proportion of aspen in the stand & & 0 & 1.7 & 2.6 & 3.8 & 12.2 \\
\hline 23 & Proportion of other species in the stand & & 0 & 0.1 & 0.4 & 2.1 & 1.5 \\
\hline 24 & $\begin{array}{l}\text { Automobile roads spacing, } \mathrm{km} \text { of roads } \\
\text { per } 1 \text { thous. ha of forest area }\end{array}$ & & 0.8 & 1.84 & 1.5 & 1.27 & 5. \\
\hline
\end{tabular}

Average volume of stem (indicator 4) has been calculated based on forest taxation data of the forest areas included into the respective ENR regions according to the expression:

$$
q_{a v}=\sum_{i=1}^{n} \frac{Q_{i} \cdot q_{a v i}}{\sum_{i=1}^{n} Q_{i}}
$$

where $q_{a v}$ - average volume of stem in the region, $Q_{i}$ - timber resources in merchantable forest for the $i$-th forest area of the certain ENR region, $q_{a v i}$ - average volume of stem for the $i$-th forest area, $n$ - total number of forest areas in the region.

Maximum volume of stem (indicator 5) is the largest value of $q_{\text {avi }}$. Minimum volume of stem (indicator 6 ) is lowest value of $q_{\text {avi }}$.

Mean height of forest stands (indicator 7) has been defined as per appraising scale applied in the RF, where, average site quality of forest and the determined felling age as per dominant coniferous species have been the input information. For this purpose data on the classification of stands in merchantable forests by site qualities and information about planned felling age have been collected and analyzed. 
Table 2. Sources of natural-production conditions indicators.

\begin{tabular}{|c|c|c|c|}
\hline No & Indicator name & Unit & Sources \\
\hline 1 & Average diameter of forest stand & \multirow[t]{3}{*}{ [cm] } & \\
\hline 2 & The most common class diameter & & Diameter distribution data given in Vinogorov's work (1972) \\
\hline 3 & Maximum diameter class & & \\
\hline 4 & Average volume of stem & \multirow{3}{*}[\mathrm{m}^{3}]{} & \multirow{3}{*}{ Forest plans of the constituents of the RF, Komi Republic geoportal (gis.rkomi.ru) } \\
\hline 5 & Maximum volume of stem & & \\
\hline 6 & Minimum volume of stem & & \\
\hline 7 & Mean height of forest stands & {$[\mathrm{m}]$} & - \\
\hline 8 & Quality class & & Freely available data of The Federal Forestry Agency of Russia \\
\hline 9 & Slope ratios Up to 15 degrees & \multirow{7}{*}[\%]{} & \multirow{7}{*}{$\begin{array}{l}\text { The data given in Lyumanov's work (1990) and specified according to the information from forest plans, physical, } \\
\text { landscape and soil maps. }\end{array}$} \\
\hline 10 & Slope ratios $16-25$ degrees & & \\
\hline 11 & Slope ratios 26 and more degrees & & \\
\hline 12 & Ratios of class 1 of soil conditions & & \\
\hline 13 & Ratios of class 2 of soil conditions & & \\
\hline 14 & Ratios of class 3 of soil conditions & & \\
\hline 15 & Ratios of class 4 of soil conditions & & \\
\hline 16 & Timber volume per ha & \multirow{3}{*}[\mathrm{m}^{3}]{} & \multirow{3}{*}{ Forest plans of the constituents of the RF } \\
\hline 17 & Minimal timber volume per ha & & \\
\hline 18 & Maximal timber volume per ha & & \\
\hline 19 & The proportion of pine in the stand & \multirow{5}{*}[\%]{} & \multirow{5}{*}{ The schematic maps of forests distribution by dominant species, forest plans of the constituents of the RF } \\
\hline 20 & The proportion of spruce in the stand & & \\
\hline 21 & The proportion of birch in the stand & & \\
\hline 22 & The proportion of aspen in the stand & & \\
\hline 23 & The proportion of other species in the stand & & \\
\hline 24 & $\begin{array}{l}\text { Automobile roads spacing, km of roads } \\
\text { per } 1 \text { thous. ha of forest area }\end{array}$ & & $\begin{array}{l}\text { Allocation maps of leases of forest resources in forest areas, schematic maps of annual allowable cut use in forest } \\
\text { areas, schematic maps of the current road networks, forest plans of the constituents of the RF }\end{array}$ \\
\hline
\end{tabular}

The indicators $12-15$ shows ratios of soil conditions classes. Class 1 includes dry sands and stony soils. Under class 1 works on felling area can be performed throughout the year almost without restrictions. Class 2 includes sandy-loam soils and fine loam soils. Under the conditions of class 2 works in felling area are limited during spring and autumn time of impassable roads due to the decrease of bearing capacity of soils. Class 3 includes clayed soils, sand loams with clay courses. Such soils have high contents of moisture during whole warm season. Working under such conditions machines ruin surface soil fast and form track pits. Class 4 includes peat-bog and humus gley soils. They become impassable during the periods of steady rains, and have low bearing capacity during dry season.

Timber volume per ha (indicator 16) for ENR regions has been determined according to the expression:

$$
S V=\sum_{i=1}^{n} Q_{i} / \sum_{i=1}^{n} S_{i}
$$

where $S V$-average timber volume per ha, $S_{i}$ - area of the $i$-th forest area.

Indicator 17 is lowest value of timber volume per ha for $i$-th forest areas in the region. Indicator 18 is largest value of timber volume per ha for $i$-th forest areas in the region.

We conducted an analysis of the natural-production conditions by comparing sets of indicators. The description of the sets is given in Table 3 .
Table 3. List of indicator sets.

\begin{tabular}{lll}
\hline Set name & Indicators & \multicolumn{1}{c}{ Description } \\
\hline NPS & all & $\begin{array}{l}\text { The set characterizes the natural-production conditions } \\
\text { on the basis of all indicators }\end{array}$ \\
ATD & $4,8,16$, & The set characterizes the average taxation data of forest \\
TMed & $19-23$ & stands (forest value) \\
TMax & $3,5,7$ & $\begin{array}{l}\text { The set characterizes the size of medium tree } \\
\text { The set characterizes the size of maximum tree }\end{array}$ \\
CLC & $9-15$ & $\begin{array}{l}\text { The set characterizes soil conditions and land form } \\
\text { conditions }\end{array}$ \\
SC & $19-23$ & The set characterizes species composition \\
\hline
\end{tabular}

\subsection{Classification of timber harvesting machines}

Two systems of logging machines are most common in Russia (Goltsev at al., 2011). The first system (HF) includes a harvester and a forwarder. The second system (FSP) includes a feller buncher, a skidder and a processor. Two types of skidders are used in Russia: with arch grapple and clambunk skidders. Excavator-based harvesters are often used as processors.

We separate three classes of logging machines: light (L), medium (M) and heavy $(\mathrm{H})$. The technical characteristics of the classes are given in Table 4.

Logging machines on a wheeled chassis and on tracked chassis are used on forest harvesting. Logging machines on a wheeled chassis have $4 \times 4,6 \times 6$ and $8 \times 8$ axle configuration and can have antiskid chains. Some forest machines used in Russia have complicated cab leveling systems and system of self-propelled chassis active stabilization. 
Table 4. Technical characteristics of logging machines classes.

\begin{tabular}{|c|c|c|c|}
\hline \multirow{2}{*}{$\begin{array}{l}\text { Name of the timber } \\
\text { harvesting machine }\end{array}$} & \multicolumn{3}{|c|}{ Technical characteristics } \\
\hline & Light class & Medium class & Heavy class \\
\hline \multirow{6}{*}{ Harvester } & Gross power: $80-120 \mathrm{~kW}$ & Gross power: $120-160 \mathrm{~kW}$; & Gross power: over $160 \mathrm{~kW}$ \\
\hline & Weight: $7-14$ ton; & Weight: 14-20 ton; & Weight: over 20 ton; \\
\hline & Diameter processed tree up to: $50 \mathrm{~cm}$ & Diameter processed tree up to: $60 \mathrm{~cm}$ & Diameter processed tree: over $60 \mathrm{~cm}$ \\
\hline & e.g.: Sampo Rosenlew 1046 X, Logman 801, & e.g.: Ponsse Beaver, Valmet 901, Logman 811H, & e.g.: John Deere 1270, John Deere 1470E, John \\
\hline & Logset 4H, Sampo Rosenlew 1066, & Logest 5H, John Deere 1070D, Logset 6H; Ponsse & Deere 608L, Ponsse Scorpion, Ponsse Bear, \\
\hline & John Deere 770D & Ergo, Ponsse Buffalo Dual; Valmet 911.3 & Ponsse Fox, Volvo EC210BF, Daewoo Sola \\
\hline \multirow{5}{*}{ Forwarder } & Gross power: $80-120 \mathrm{~kW}$ & Gross power: $120-160 \mathrm{~kW}$; & Gross power: over $160 \mathrm{~kW}$ \\
\hline & Lift capacities: up to 12 ton & lift capacities: $12-15$ ton & Lift capacities: over 15 ton \\
\hline & e.g.: Komatsu 835, Ponsse 10 w, Ponsse & e.g.: Komatsu 855, Ponsse Elk, Ponsse Wisent, & e.g.: Komatsu 895, Ponsse Elephant King, Ponsse \\
\hline & Gazelle, John Deere 1010E; Gremo 950 F, & John Deere 1510E; Caterpillar 574; & Elephant, John Deere 1910E, Caterpillar 584, \\
\hline & HSM 208F 8,5t, Logset 5F & HSM 208F 14t, Logset 6F & $\begin{array}{l}\text { HSM 904F, Logset 10F; } \\
\text { TimberPro TF830-B. }\end{array}$ \\
\hline \multirow{6}{*}{ Feller buncher } & Gross power: up to $120 \mathrm{~kW}$ & Gross power: $120-180 \mathrm{~kW}$; & Gross power: over $180 \mathrm{~kW}$ \\
\hline & Weight: up to 15 ton; & Weight: $15-20$ ton; & Weight: over 25 ton; \\
\hline & Diameter processed tree: up to $40 \mathrm{~cm}$ & Diameter processed tree: up to $50 \mathrm{~cm}$ & Diameter processed tree: over $50 \mathrm{~cm}$ \\
\hline & e.g.: DFM Compact Feller Buncher, & e.g.: John Deere 753J, John Deere 759J, & e.g.: John Deere 853J, John Deere 903J, \\
\hline & Delfab DF703 Phoenix & Caterpillar 511, Valmet 415FX, & John Deere 959J, Caterpillar 521, Caterpillar 552, \\
\hline & & John Deere PowerTech 6068H & Valmet 445FXL, Tigercat 822C \\
\hline \multirow{5}{*}{ Skidder } & Gross power: up to $80 \mathrm{~kW}$ & Gross power: $80-160 \mathrm{~kW}$; & Gross power: over $160 \mathrm{~kW}$; \\
\hline & Weight: 5-10 ton; & Weight: $10-15$ ton; & Weight: over 15 ton; \\
\hline & Capacity clam bunk (arch grapple): up to $8 \mathrm{~m}^{3}$ & Capacity clam bunk (arch grapple): $8-14 \mathrm{~m}^{3}$ & Capacity clam bunk (arch grapple): over $14 \mathrm{~m}^{3}$ \\
\hline & & e.g.: John Deere 640L, John Deere 648L, & 48L, John Deere 848L, \\
\hline & e.g.: Turboforest T42-C, Awassos MD-80 & $\begin{array}{l}\text { Cat 525D, Cat 535D, Tigercat 610E, } \\
\text { HSM } 8056 \text { WD }\end{array}$ & $\begin{array}{l}\text { TimberPro TS820-D, Clam Bunk, } \\
\text { HSM } 904 \text { 6WD }\end{array}$ \\
\hline \multirow{5}{*}{ Processor } & Gross power: $80-120 \mathrm{~kW}$; & Gross power: $120-160 \mathrm{~kW}$; & Gross power: over $160 \mathrm{~kW}$ \\
\hline & Weight: up to 15 ton; & Weight: 15-30 ton; & Weight: over 30 ton; \\
\hline & Diameter processed tree: up to $50 \mathrm{~cm}$ & Diameter processed tree: up to $60 \mathrm{~cm}$ & Diameter processed tree: over $60 \mathrm{~cm}$ \\
\hline & e.g.: Hypro 755 VB, Hypro 450 XL, & e.g.: John Deere 2154G, Prentice 2384C, 2484C, & e.g.: John Deere 803MH, 853MH, 859MH, \\
\hline & Hypro 300 & Komatsu PC200 & $\begin{array}{l}\text { 2654G, Tigercat 860C, Caterpillar H822D, } \\
\text { LH822D }\end{array}$ \\
\hline
\end{tabular}

\section{Results}

\subsection{Assessment of the similarity of natural- production conditions}

Comparison of NPS sets (name set, see table 3) showed that the natural-production conditions of the Republic of Karelia are the closest to the natural-production conditions of Arkhangelsk region (ED 3.63). The most different are the natural-production conditions of Murmansk region and Vologda region (ED 9.91). The natural-production conditions of Komi Republic are closest to Arkhangelsk region (ED 4.96) and to the Republic of Karelia (ED 5.41). The natural-production conditions of Murmansk region and Vologda region are the most different from the natural-production conditions of other ENR regions. ED are in the range 6.45-9.91 for Murmansk Region and 5.94-9.91 for Vologda Region. Fig. 3 gives dendrogram of Euclidean distances between five studied regions calculated using cluster analysis based on NPS sets describing various aspects of natural-production conditions.

Comparison of ATD sets showed that the average taxation data of forest stands of Murmansk region and the Republic of Karelia are the most similar (ED 1.98). The average taxation data Arkhangelsk region are most similar to the average taxation data of the Republic of Komi (ED 2.08). The average taxation data of Vologda region is the most different from the average taxation data of other regions in particular Murmansk region (Fig. 4).

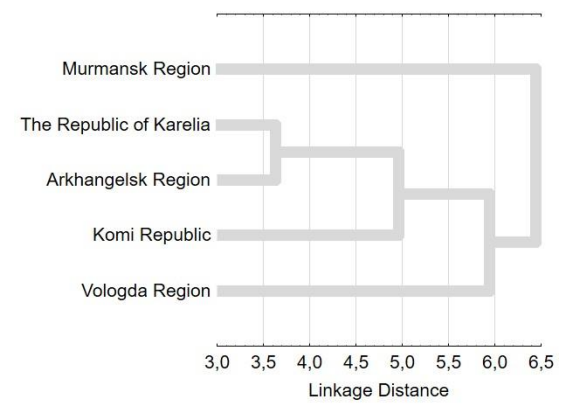

Fig. 3. Dendrogram of Euclidean distances between five studied regions calculated using cluster analysis based on NPS sets describing various aspects of natural-production conditions.

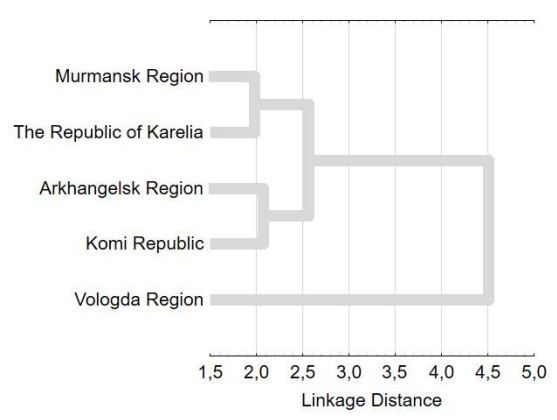

Fig. 4. Dendrogram of Euclidean distances between five studied regions calculated using cluster analysis based on ATD sets describing various aspects of natural-production conditions. 
Fig. 5 gives the results of TMed sets comparison and Fig. 6 gives the results of TMax sets comparison.

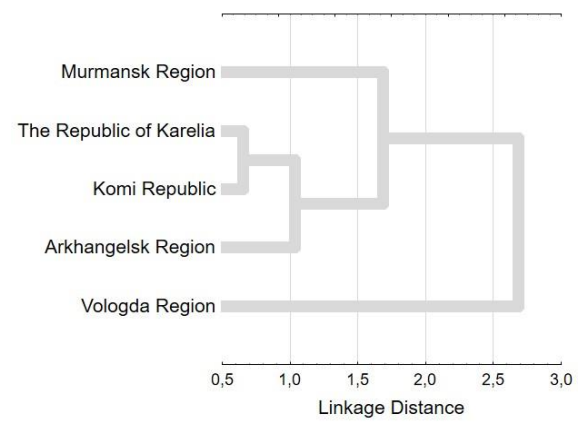

Fig. 5. Dendrogram of Euclidean distances between five studied regions calculated using cluster analysis based on TMed sets describing various aspects of natural-production conditions.

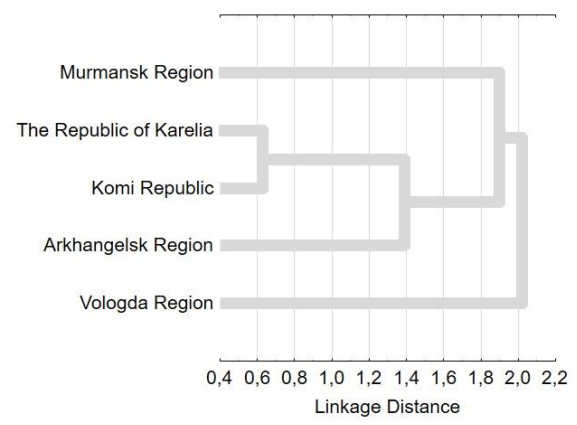

Fig. 6. Dendrogram of Euclidean distances between five studied regions calculated using cluster analysis based on TMax sets describing various aspects of natural-production conditions.

The sizes of maximum tree and medium tree are close in The Republic of Karelia and in Komi Republic (ED 0.63 and 0.65 respectively). From all ENR regions, sizes of trees are close in three regions (the Republic of Karelia, Komi Republic and Arkhangelsk Region). ED are in the range 0.6-1.07 for TMed sets and 0.63-1.79 for TMax sets. The sizes of maximum trees and medium trees in Vologda Region and in Murmansk Region are the most different from maximum and medium sizes of trees in other ENR regions. ED are in the range 1.9-3.91 for Murmansk Region and 2.02-3.91 for Vologda Region. Murmansk Region and Vologda Region differ most by these sets (ED 3.91).

Fig. 7 gives the results of CLC sets comparing. The soil conditions and the land form conditions are most similar in Arkhangelsk Region and Vologda Region (ED 0.67). The Republic of Karelia is approaching these regions by these conditions. The soil conditions and the land form conditions of Murmansk Region and Komi Republic are vary most considerably from other ENR regions. ED for Murmansk Region are greater than 3.9. ED for Komi Republic are greater than 3.3 .

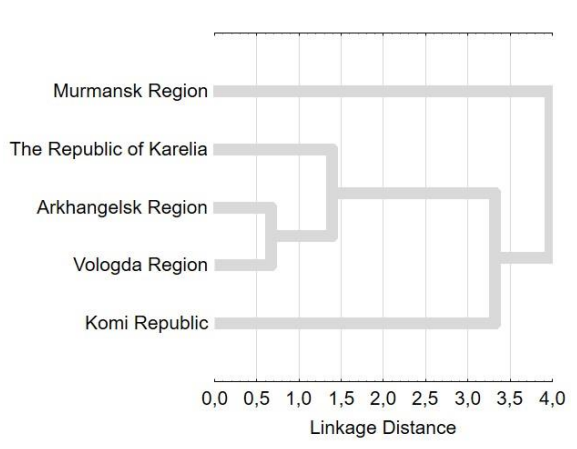

Fig. 7. Dendrogram of Euclidean distances between five studied regions calculated using cluster analysis based on CLC sets describing various aspects of natural-production conditions.

Fig. 8 gives the result of SC sets comparison. The forests of Murmansk region are similar to the forests of the Republic of Karelia by their species composition (ED 0.41). The forests of Arkhangelsk Region are similar to the forests of Komi Republic by their species composition (ED 2.01). The species composition of forests in Vologda region is very different from other ENR regions (ED > 3.6). The forests of Vologda region are most significantly different from the forests of Murmansk region in terms of species composition (ED 4.05).

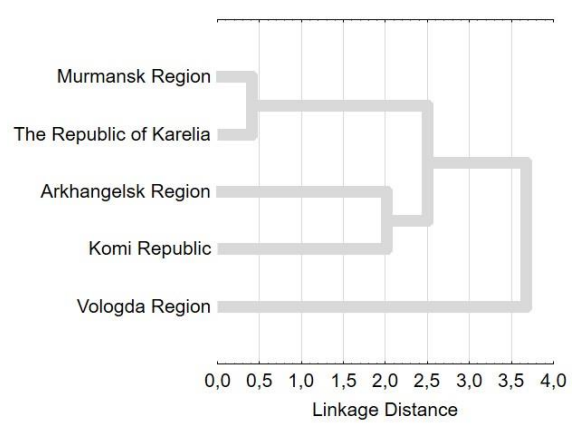

Fig. 8. Dendrogram of Euclidean distances between five studied regions calculated using cluster analysis based on SC sets describing various aspects of natural-production conditions.

Based on the results of cluster analysis in ENR, three zones of natural-production conditions can be identified (Fig. 9). Zone A includes Murmansk region. Zone $B$ includes the Republic of Karelia, Komi Republic and Arkhangelsk Region. Zone C includes Vologda Region. Analysis of soil conditions and land form conditions and 9-15 indicators showed that it is advisable to allocate subzones B1 and B2. These subzones take into account the presence of undulating topography unusual for zone B. Zone B1 includes West Karelian upland. Zone B2 includes Northern Urals, Subpolar Urals, Polar Urals. 


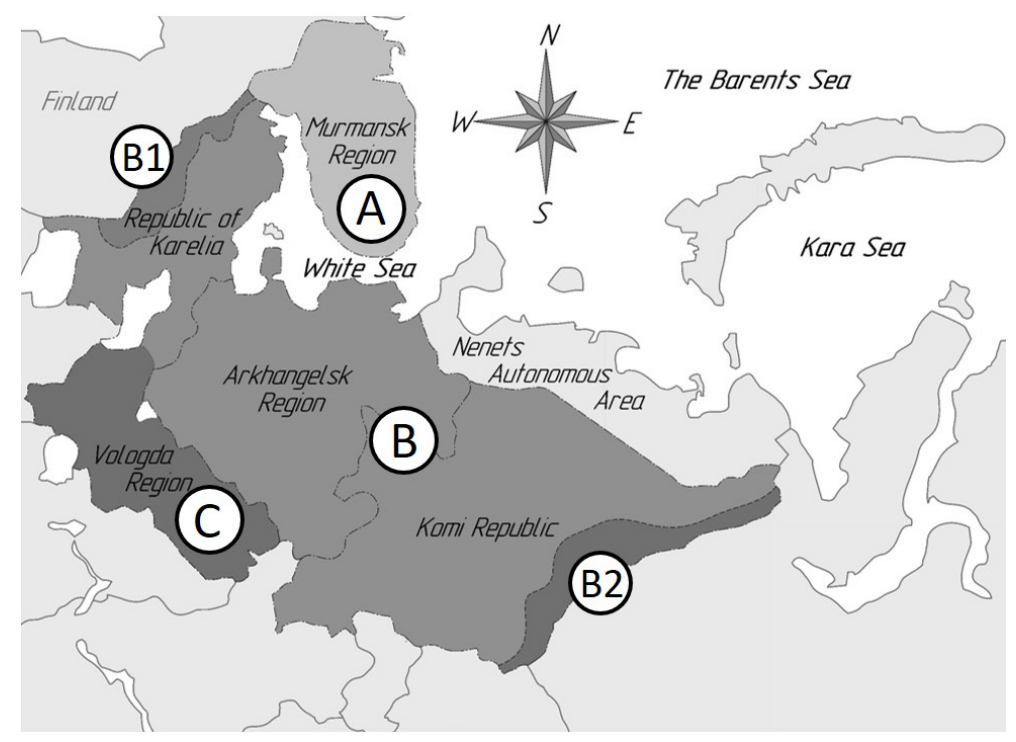

Fig. 9. Zones of natural-production conditions in ENR.

\subsection{Comparison of technical characteristics} of logging machines and natural-production conditions

The comparison of natural-production conditions and technical characteristics of logging machines allowed to make recommendations on the systems of logging machines that can be used in ENR regions. Table 5 summarizes the results of the comparison.

HF system is most applicable in all ENR regions for small logging enterprises. However, for zone A, HF system should be formed from $L$ class of logging machines, for zone $\mathrm{B}$ from $\mathrm{M}$ or $\mathrm{H}$ class, for zone $\mathrm{C}$ from $\mathrm{H}$ class. FSP system can be used in Vologda Region, especially in its southern part.

Soil conditions of classes 3 and 4 predominate in ENR regions, except for Murmansk Region. High bogginess is typical for Komi Republic, The Republic of Karelia, Arkhangelsk and Vologda Regions. Therefore, in B and $\mathrm{C}$ zones (except for B1 and B2 subzones) it is necessary to use either logging machines on a tracked chassis or on a wheeled chassis with tracks for wheels and $6 \times 6$ or $8 \times 8$ axle configuration. In B1 and B2 subzones, the feasibility of using wheeled chassis with $6 \times 6$ or $8 \times 8$ axle con- figuration is explained by the need to ensure stability on slopes. Logging machines with $6 \times 6$ or $8 \times 8$ axle configuration have better stability. The use of tracks for wheels is explained by a decrease in the negative impact on the soil. Tracks for wheels are used to ensure passableness of logging machines in $\mathrm{B}$ and $\mathrm{C}$ zones.

Logging machines may be not equipped with cab leveling system and system of self-propelled chassis active stabilization in Vologda Region and Arkhangelsk Region and The Republic of Karelia (zones B and C except for B1 and B2 subzones) because relief on the forest areas of these regions is mainly characterized by slopes with less than $15^{\circ}$ slope ratios. Areas of forest stands in zone A and subzones B1 and B2 (Murmansk Region and the part of Komi Republic and the part of The Republic of Karelia) are defined by the most rugged topography. Almost all the territory of Murmansk Region has an undulating land. In this region, logging machines must be equipped with cab leveling systems and system of self-propelled chassis active stabilization. Such systems should be equipped with machines used in the Western part of the Republic of Karelia (zone B1) and the Eastern part of Komi Republic (zone B2).

Table 5. Logging machines systems.

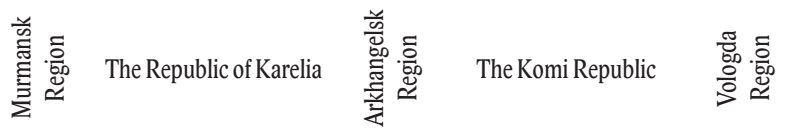

\begin{tabular}{|c|c|c|c|c|c|c|c|}
\hline Zone & $\mathrm{A}$ & B & B1 & $\mathrm{B}$ & B & B2 & $\mathrm{C}$ \\
\hline Systems of logging machines & $\mathrm{HF}$ & $\mathrm{HF}$ & $\mathrm{HF}$ & $\mathrm{HF}$ & $\mathrm{HF}$ & $\mathrm{HF}$ & HF/FSP \\
\hline Logging machines on a tracked chassis & - & + & - & + & + & - & + \\
\hline $\begin{array}{l}\text { Tracks for wheels } \\
\text { Cab leveling systems and system of self-propelled chassis active stabilization }\end{array}$ & $\overline{+}$ & - & + & $\stackrel{+}{-}$ & 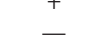 & $\begin{array}{l}+ \\
+\end{array}$ & $\stackrel{+}{-}$ \\
\hline
\end{tabular}




\section{Discussion}

Our results indicated high variability of natural-production conditions in the ENR regions. Except for Murmansk Region, ENR regions are similar in soil conditions and land form conditions. Species composition varies in ENR regions, however prevailing species are analogous. Sizes of trees in forest stands are the most considerable difference between ENR regions. Actually ENR regions can be divided into three groups by sizes of trees in forest stands. Murmansk Region refers to the first group which is characterized by the smallest sizes of trees. The second group described by middle-sized trees includes the Republic of Karelia, Komi Republic and Arkhangelsk Region. Vologda Region refers to the third group defined by the largest trees in forest stands.

The study evidence that in ENR there are several zones with the same natural-production conditions. The zones have special aspects that must be considered when choosing logging machines. Currently, the logger is trying to purchase heavy logging machines but the results indicate that all classes of logging machines can be used in ENR. Thus, the logging approach can be more flexible even for small enterprises.

In addition, the study showed that for small enterprises it is advisable to use HF system. This system is more universal for ENR than FSP system in ENR. As disadvantages of FSP system for ENR, experts noted machinery downtime associated with expectation of relocation. The sizes of cutting areas in ENR are small (10-15 hectares). FSP system has high productive so it processes the cutting area quickly. There is a need for frequent relocations. FSP system consists of three logging machines as against HF system that has two machines. The problem is complicated by the fact that in the most part of ENR has a low road density (indicator 24), and a relatively small hectare timber volume per ha (indicator $24)$. This leads to an increase in the relative cost of logging and machinery downtime. In general, FSP system requires a higher level of planning of logging operations under natural-production conditions of ENR. FSP system is advisable to use in Vologda region, where the forest is larger and higher level of road density. Disadvantages of FSP system for ENR are impossibility of strengthening skidding road with wood residues and contamination of wood while skidding.

These results are consistent with the results of Syunev et al. (2009), Goltsev et al. (2011) who presented a comparative appraisal of using logging system in Northwest of Russia.

For zones B and C, we do not recommend using logging machines with cab leveling system and system of self-propelled chassis active stabilization. This is because logging machines equipped with the systems tend to be more expensive than machines without such the systems and relief has relatively mild slopes (up to $15^{\circ}$ ) in the zones. Under such approach ergonomic working condi- tions of a logging machine operator deteriorate, but at the same time machine price and service charge will be considerably lower what is mostly important for small enterprises.

In our study, we used 46-year old data on diameter distribution given in Vinogorov (1972). The data were obtained from the measurement of 4.8 million trees. Conducting such a number of measurements is currently difficult. It is known from forest estimation that diameter distribution is subject to certain objective laws (Tyabera 1980; Picard et al. 2016). Conditions of habitat, species composition, age, density of stand, configuration of stand, economic activity in forest, environmental drivers, natural catastrophes, in particular fires, hurricanes, are the factors influencing diameter distribution in forest stand. Diameter distribution changes over time (Vacek et al. 2018).

According to Russian legislation, logging can only be carried out in forests that have reached a certain age. This age has not changed since the time of Vinogorov's research. Thus, we consider forests of the same age. We compared the data on the average volume of stem and the average timber volume per ha corresponding to the time of Vinogorov's research, with modern data. The data does not differ. Therefore, we consider it possible to use the Vinogorov's data for the present-day planning.

All conclusions are based on analysis, the available data and own sample observations. There are reasons that may limit the significance of the research results. First, it is reliability of the data used in the study. Secondly, it is limited number of the indicators used in the study that characterize natural and production conditions. In addition, the opinion of experts, whose objectivity is limited, was used in the development of recommendations on logging machines.

Small enterprises can use the results of the study in the planning of logging operations. In addition, the method of allocation of territories with similar naturalproduction conditions based on cluster analysis can be used by logging enterprises in the analysis of their own allocated timber supply area. Besides the researches findings are currently important for a buyer of logging machine allowing to make a well grounded choice of certain model among the whole variety of designs, and for a seller allowing to assess the characteristics of his models in the context of forest exploitation conditions of certain regions and make a commercial proposal based on the results of such assessment.

\section{Conclusion}

In consequence of the conducted study, it has been established that natural-production conditions in ENR regions are similar in relief and soil conditions. ENR regions vary most considerably in sizes of trees in forest stands and timber volume per ha. From the results, 
ENR can be divided into three main zones A, B, C and two subzones $\mathrm{B} 1$ and $\mathrm{B} 2$ with similar natural-production conditions. In the zones A, B and the subzones B1 and B2, small logging enterprises should use a harvester and a forwarder. In the zone $\mathrm{C}$, the enterprises can use a logging system including a harvester and a forwarder or a logging system including a feller buncher, a skidder and a processor. The logging system should be based on the light class of logging machines for the zone $\mathrm{A}$, the medium class or the heavy class for the zones B, C and the subzones B1, $\mathrm{B} 2$, the heavy class of machines for the zone $\mathrm{C}$.

\section{Acknowledgments}

The researches have been performed within the frameworks of implementing grant of the President of the Russian Federation No MK-5321.2018.8.

\section{References}

Ackerman, S., F., Ackerman, P. ,Williams, C., Nathi, C., 2017: Diesel Consumption and Carbon Balance in South African Pine Clear-Felling CTL Operations: a Preliminary Case Study. Croatian Journal of Forest Engineering, 38:65-72.

Alam, M., Walsh, D., Strandgard, M., Brown, M., 2014: A Log-by-Log Productivity Analysis of Two Valmet 475EX Harvesters. International Journal of Forest Engineering, 25:14-22.

Bergroth, J., Palander, T., Kärhä, K., 2006: Excavatorbased harvesters in wood cutting operations in Finland. Forestry Studies, 45:74-88.

Castro, G. P., Malinovski, J. R., Nutto, L., Malinovski, R. A., 2016: Harvesting Systems. Tropical Forestry Handbook. Springer, Berlin, Heidelberg, p. 24452485.

Eliasson, L., 1998: Analyses of single-grip harvester productivity. Doctoral thesis. Swedish University of Agricultural Sciences, Department of Operational Efficiency, Umeå, $24 \mathrm{p}$.

Glöde, D., 1999: Single- and double-grip harvesters productive measurements in final cutting of shelterwood. Journal of Forest Engineering, 10:63-74.

Goltsev, V., Tolonen, T., Syunev, V., Dahlin, B., Gerasimov, Y. et al., 2011: Wood harvesting and logistics in Russia. Working Papers of the Finnish Forest Research Institute, 210 p. Available at: http://www. metla.fi/julkaisut/workingpapers/2011/mwp210. htm

Häggström, C., Lindroos, O., 2016: Human, technology, organization and environment - a human factors perspective on performance in forest harvesting. International Journal of Forest Engineering, 27:67-78.
Jiroušek, R., Klvac, R., Skoupý, A., 2007: Productivity and costs of the mechanised cut-to-length wood harvesting system in clear-felling operations. Journal of Forest Science, 53:476-482.

Kärhä, K., Rönkkö, E. \& Gumse S.-I., 2004: Productivity and cutting costs of thinning harvesters. International Journal of Forest Engineering, 15:43-56.

Kellogg, L. D., Bettinger, P., 1994: Thinning productivity and cost for mechanized cut-to-length system in the Northwest Pacific coast region of the USA. Journal of Forest Engineering, 5:43-52.

Kellogg, L., D., Bettinger, P., 1994:Thinning Productivity and Cost for a Mechanized Cut-to-Length System in the Northwest Pacific Coast Region of the USA. Journal of Forest Engineering, 5:43-54.

Klaes, B., Struck, J., Schneider, R., Schueler, G., 2016: Middle-term effects after timber harvesting with heavy machinery on a fine-textured forest soil. European Journal of Forest Research, 135:1083-1095.

Kormanek, M., Baj, D., 2018: Analysis of Operation Performance in the Process of Machine Wood Harvesting with Fao Far 6840 Mini-Harvester. Agricultural Engineering, 22:73-82.

Laitila, J., Väätäinen, K., 2013: The cutting productivity in integrated harvesting of pulpwood and delimbed energy wood with a forestry-equipped peat harvesting tractor. Suo, 64:97-112.

Lyumanov, R., 1990: Mašinnaja valka lesa. Moscow, Timber industry, $280 \mathrm{p}$.

McNeel, J., F., Rutherford, D., 1994: Modeling harvesterforwarder system performance in a selection harvest. Journal of Forest Engineering, 6:7-14.

Nurminen T., Korpunen H., Uusitalo J., 2006: Time consumption analysis of the mechanized cut-to-length harvesting system. Silva Fennica, 40:335-363.

Ovaskainen, H., 2005: Comparison of harvester work in forest and simulator environments. Silva Fennica, 39:89-101.

Palander, T., Bergroth, J., Kärhä, K., 2012: Excavator technology for increasing the efficiency of energy wood and pulp wood harvesting. Biomass and Bioenergy, 40:120-126.

Pētersons, J., 2014: Productivity of harvesters in commercial thinnings in the forest stands of different composition of species. Research for rural development, 2:76-82.

Picard, D., Gasparotto, D., 2016: Liocourt's law for tree diameter distribution in forest stands. Annals of Forest Science, 73:751-755.

Proto, A. R., Macrì, G., Visser, R., Harrill, H., Russo, D., Zimbalatti, G., 2018: Factors affecting forwarder productivity. European Journal Forest Research, Available at: https://doi.org/10.1007/s10342-017-1088-6

Reza, N., Bagheri, I., Lotfalian, M., Setodeh, B., 2009: Rutting and soil displacement caused by 450C Timber Jack wheeled skidder (Asalem forest northern Iran). Journal of Forest Science, 55:177-183. 
Rozītis, A., Zimelis, A., Lazdins,A., 2017: Evaluation of productivity and impact on soil of tracked ProSilva F2/2 forwarder in forest thinning. Research for Rural Development, 1:94-100.

Schack-Kirchner, H., Fenner, P., T., Hildebrand, E. E., 2007: Different responses in bulk density and saturated conductivity to soil deformation by logging machinery on a Ferralsol under native forest. Soil Use and Management, 23:286-293.

Strandgard, M., Mitchell, R., Acuna, M., 2017:Timeconsumption and productivity of a forwarder operating on a slope in a cut-to-length harvest system in a Pinus radiata D. Don pine plantation. Journal of Forest Science, 63:324-330.

Syunev, V., Sokolov, A., Konovalov, A., Katarov, V., Seliverstov, A., Gerasimov, Y. et al., 2009: Comparison of Wood Harvesting Methods in the Republic of Karelia. Working Papers of the Finnish Forest Research Institute, 120 p. Available at: http://www.metla.fi/ julkaisut/workingpapers/2009/mwp120.htm

Tiernan, D., Zeleke, G., Owende, P., M., O., Kanali, C., L., Lyons, J., Ward, S., M., 2004: Effect of working conditions on for-warder productivity in cut-tolength timber harvesting on sensitive forest sites in Ireland. Biosystems Engineering, 87:167-177.
Tufts, R. A., 1997: Productivity and cost of the Ponsse 15-series, cut-to-length harvesting system in southern pine plantations. Forest Products Journal, 47:3946.

Tyabera, A. P., 1980: Principy issledovanij stroenija drevostoev po tolščine derevjev. Forest Journal, $1: 5-9$.

Vacek, Z., Vacek, S., Bílek, L., Král, J., Ulbrichová, I., Simon, J., Bulušek, D., 2018: Impact of applied silvicultural systems on spatial pattern of hornbeamoak forests. Central European Forestry Journal, 64:33-45.

Vinogorov, G. K., 1972:K metodike obosnovanija rasčetnych derevjev prirešenii lesoekspluatacionnych zadač. Works of TSNIME, 122:52-64.

Vinogorov, G. K., 1986: Tipizacija prirodnoproizvodstvennych uslovij lesozagotovitel'nych rajonov. TSNIME, Ximki, $23 \mathrm{p}$.

Wang, J., Haarla, R., 2002: Production analysis of an excavator-based harvester: a case study in Finnish forest operations. Forest Product Journal, 52:85-90. 